\title{
Characteristics of Mesozoic-Cenozoic tectonic diagenesis in the Kuqa area of the Tarim Basin, China
}

\author{
Shou Jianfeng*, Shen Yang, Zhang Huiliang and Zhang Ronghu
}

Hangzhou Research Institute of Petroleum Geology, PetroChina, Hangzhou, Zhejiang 310023, China

\begin{abstract}
Tectonic diagenesis is a common and important geological phenomenon. We can fully understand the diagenesis of compressional basins through studying tectonic diagenesis. In this paper, we presented the tectonic diagenetic characteristics in the Kuqa area of the Tarim Basin by integrated method of geological analysis and paleotectonic stress. The results showed that the Mesozoic-Cenozoic tectonic diagenesis affected sandstone compaction evolution mainly through physical mechanisms. It showed characteristics of abrupt change and nonthermal indicator (it means that sandstone compaction can not be explained by thermal diagenetic compaction alone because actual sandstone compaction was larger than thermal compaction), which were different from the thermal and fluid diagenesis. Compared with thermal diagenesis, tectonic diagenesis had a typical tectonic compaction in very short time, and many phases of tectonic deformation showed multiple abrupt changes of compaction. There are obvious differences between tectonic and thermal diagenetic compaction, leading to sandstone compaction being larger than the thermal compaction under the same thermal evolution stage in the areas where tectonic deformation happened. The stronger the tectonic deformation, the more obvious the difference. Tectonic process changed the stress distribution through changing the tectonic deformation styles, resulting in different tectonic diagenesis effects. Therefore, tectonic diagenesis of Mesozoic-Cenozoic in the Kuqa area can be divided into four types including rigid rock restraint, fault ramp, low angle fault slippage, and napping.
\end{abstract}

Key words: Sandstone reservoirs, tectonic deformation, tectonic diagenesis, controlling factors, Kuqa area

\section{Introduction}

Among Chinese sedimentary basins, from high geothermal basins to low geothermal basins, from acid diagenetic water to neutral-alkaline diagenetic water environment, from craton basins to foreland area, even from one part to another part in the same local structure, there are a great deal of difference in clastic rock diagenesis, which can not be explained reasonably by traditional diagenesis theories. Especially in the strong tectonic compression areas of the basins in middle and west China, the changing characteristics and controlling factors of clastic rock diagenesis are not explained by the traditional buried diagenesis theory. For example, in the Kuqa area of the Tarim Basin, usual parameters such as depth and temperature that reflect diagenesis evolution can not explain the observed sandstone diagenesis phenomenon (Shou et al, 2003; 2006a; 2007). The complex sedimentation, structure, heat flow, and fluid process in Chinese basins intensely controlled the diagenesis evolution of clastic rock, and made the controlling factors very complex. Clastic diagenesis can be divided into thermal diagenesis, tectonic diagenesis, and

*Corresponding author. email: shoujf_hz@petrochina.com.cn Received April 1, 2009 fluid diagenesis (Shou et al, 2006b). Thermal diagenesis is controlled by the reservoir temperature, and especially influenced by the geothermal gradient. Thermal maturity is a good indicator reflecting thermal diagenesis evolution. Fluid diagenesis including the influence of fluid properties and fluid activities on diagenesis is very complex. Past research is not adequate and what concerns geologists is the position, number, and controlling factors of the water-rock reaction products. Tectonic diagenesis in this paper means that during thermal diagenesis process, the clastic rocks are also affected by tectonic deformation, leading to a abrupt change in the evolution of diagenesis. The influencing factors include intensity (or tectonic stress), style, and occurrence time of tectonic deformation. The tectonic deformation intensity is the main driving force for tectonic diagenesis. Tectonic deformation timing indirectly affects tectonic diagenesis, and tectonic deformation styles are expressed by changing the distribution of tectonic deformation intensity.

Previous research on the Mesozoic-Cenozoic diagenesis of clastic reservoirs in the Kuqa area ( $\mathrm{Gu}$ et al, 2001; Kuang et al, 2003; Wang and Shou, 2001; Yang et al, 2005) focused on the thermal diagenesis. Based on the previous research (Shou et al, 2003; 2006a; 2006b; 2007), we further investigated 
the relationships between tectonic deformation and clastic diagenesis and pore evolution, and concluded that tectonic deformation changed the sandstone compaction mainly through physical mechanism and showed the characteristics of abrupt change and nonthermal indicator. According to the mechanism and effects, tectonic diagenesis can be divided into four types including rigid rock restraint, fault ramp, low angle fault slippage and napping. This helps the understanding of the characteristics of clastic rock diagenesis in Chinese compressional basins.

\section{Regional geological background and basic reservoir characteristics}

\subsection{Regional geological background}

The Kuqa area lies in the north of the Tarim Basin, between the South Tianshan Mountain orogenic zone and North Tarim Uplift, with an area of $29,000 \mathrm{~km}^{2}$ (Fig. 1). This area consists of six secondary structure units from north to south, including the wedge-shaped structural belt of the South Tianshan Mountain front, fault-transmitting-folded belt of Kumugeliemu-Yiqikelike, structural belt of TugeermingJidike, Baicheng Pull-Apart Depression, structural belt of Qiulitage, and structural belt of Kuqa-Yaken (Jia, 1997), filling upper Permian, Triassic, Jurassic, Cretaceous, Tertiary, and Quaternary clastic strata. The lower Jurassic, Cretaceous, and Paleogene host the main hydrocarbon-bearing formations, and are discussed in this paper. The tectonic evolution in this area underwent four stages, including early period of foreland basin evolution in late Permian, main development period of foreland basin in Triassic, Jurassic-Paleogene faulted basin period, and regenerated foreland basin period since Paleogene Oligocene (Liu et al, 2000). Since the Cretaceous, this area has been under a tectonic compressional environment. Especially since Miocene, with the steep uplift of the Tianshan Mountain orogenic zone, multiple strong nappe thrust compressions from north to south have occurred (Liu, 1996), which influenced the characteristics of the MesozoicCenozoic sandstone reservoirs.

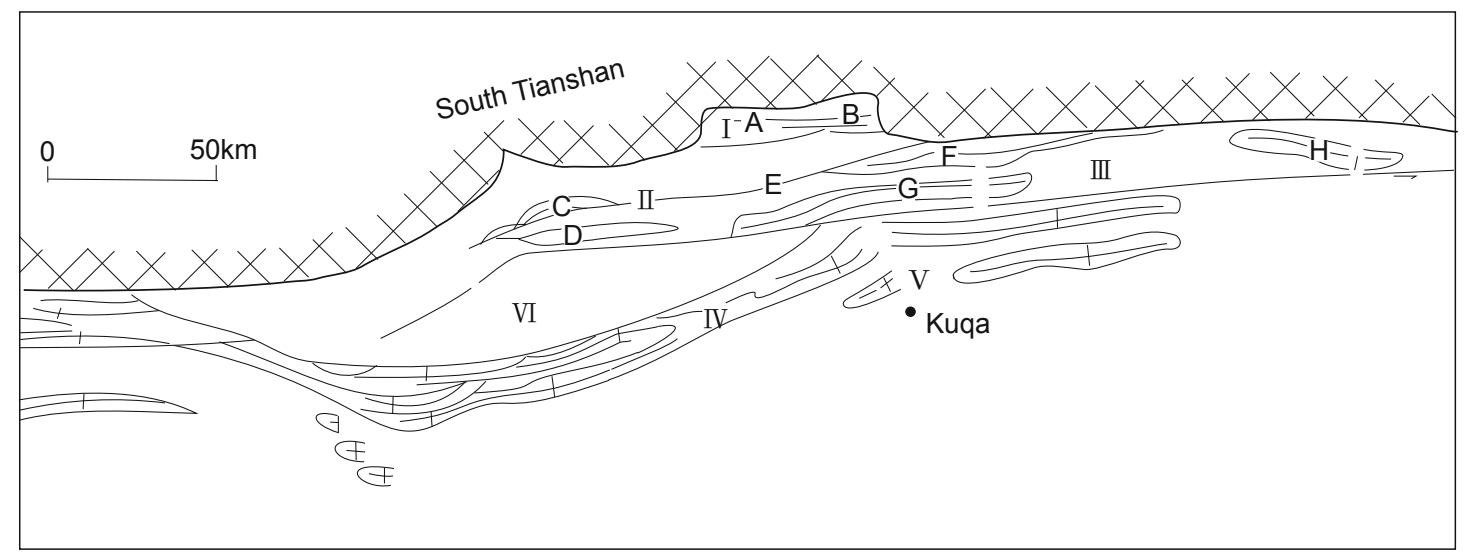

Fig. 1 Tectonic map of the Kuqa Depression (Jia, 1997)

I: South Tianshan Front Structural Belt II: Yiqikelike-Kumugeliemu Structural Belt III: Tugeerming-Jidike Structural Belt IV: Qiulitage Structural Belt V: Kuqa-Yaken Structural Belt VI: Baicheng Pull-Apart Basin A: Sideke Anticline B: Dongfeng Anticline C: Kumugeliemu Anticline D: Kasangtuokai Anticline E: Bashijiqike Anticline F: Kanyaken-Yiqikelike Anticline G: Jidike Anticline H: Tugeerming Anticline

\subsection{Basic characteristics of clastic reservoirs}

The petrology characteristics vary greatly in the MesozoicCenozoic clastic reservoirs in the Kuqa area. The deposits in lower Jurassic are mainly fine lithic sandstones to lithic conglomerates of braided river delta facies. The sandstone sorting is moderate to good, its compositional maturity index is between 0.71 and 0.77 , matrix content is mainly between $2.0 \%$ and $3.0 \%$, and the cement content is usually less than $5.0 \%$. The deposits in the Cretaceous are alluvial fan, fan delta, and braided river delta facies. The sandstone compositional maturity is a little higher than that of the lower Jurassic, between 0.97 and 1.2 , and the textural maturity is lower than that of the lower Jurassic. Comparatively speaking, the textural maturity of the Cretaceous sandstone in the east and west of this area is higher than that in the middle area, but the textural maturity in the Qiulitage structural belt is higher than that in the Ke-Yi structural belt. The compositional maturity and textural maturity of Tertiary sandstones are considerably lower than those of Cretaceous, and vary greatly in the area.

The sandstone porosity and permeability also vary a lot in the Mesozoic-Cenozoic reservoirs. The measured porosity of the lower Jurassic sandstone in the south limb of the Tugeerming anticline and Mingnan- 1 well is $15 \%-25 \%$, and permeability is $10.0 \times 10^{-3} \mu^{2}-100.0 \times 10^{-3} \mu \mathrm{m}^{2}$, even over $1,000 \times 10^{-3} \mu \mathrm{m}^{2}$. The planar porosity under a petrographic microscope is $6 \%-10 \%$, and clastic grains mainly contact with each other in the way of line and spot-line. However, the sandstone porosity in the north of the Tugeerming anticline, outcrop profile of Kezilenuo, outcrop profile of Kuqa River, and Yinan area is $6 \%-8 \%$. The permeability is generally smaller than $1.0 \times 10^{-3} \mu \mathrm{m}^{2}$, and the planar porosity under 
the petrographic microscope approaches zero. The clastic grains mainly contact with each other in the way of line and embedment, and shear fractures develop. The measured porosity of Cretaceous sandstone in the Kela 2 area is $10 \%$ $20 \%$, and its permeability is $1.0 \times 10^{-3} \mu \mathrm{m}^{2}-100.0 \times 10^{-3} \mu \mathrm{m}^{2}$. The sandstone porosity in the Dabei area is $2 \%-8 \%$, and permeability is usually smaller than $1.0 \times 10^{-3} \mu \mathrm{m}^{2}$. The burial depth of well Dongqiu- 8 in the Qiulitage structural belt is deeper than that in the Kela 2 area, close to that in the Dabei area, but the reservoir quality is better than the Kela 2 area, especially much better than the Dabei area. The measured porosity and permeability of the well Dongqiu- 8 are $16.9 \%$ $20.8 \%$ and $23.8 \times 10^{-3} \mu \mathrm{m}^{2}-776.0 \times 10^{-3} \mu \mathrm{m}^{2}$, respectively.

The relative content of primary pores as a fraction of the total porosity in sandstone reservoirs is over $75 \%$. Carbonate, kaolinite, and silica are the main filling cements, and the total content is about 5\%. From the lower Jurassic to Tertiary, the cement content is increasing, which of Cretaceous and Tertiary sandstone is as high as $10 \%-20 \%$. Overall, compaction is still the main cause of decreased porosity, and varies a lot in the area, even under similar sedimentary facies, lithology, buried depth or reservoir temperature conditions. The sandstone is more compacted than would be expected from thermal diagenesis alone.

\section{Characteristics of tectonic diagenesis}

Because the thermal diagenetic effect of tectonic rubbing process was very weak (Qiu et al, 1998), the tectonic diagenesis was mainly generated by physical forces, and it affected the compaction evolution and also changed the reservoir properties by forming fractures.

According to the dynamic mechanism of tectonic diagenesis, if there is effective tectonic stress, tectonic diagenesis will occur. This is very common in sedimentary basins in the middle and west China. The Kuqa area, located at the north frontier of the Tarim Basin, underwent a series of strong tectonic events in the Mesozoic-Cenozoic, and is an ideal target for tectonic diagenesis research. The measurement of paleotectonic stress is the key for the tectonic diagenesis research. Acoustic emission is an effective method for measuring the paleotectonic stress (Liu and Zeng, 2004; Ding et al, 1997; Zhang et al, 2004). We have studied paleotectonic stress and its diagenetic effect in the Kuqa area since 1998 (Shou et al, 2003; 2006a; 2006b; 2007). Compared with thermal diagenesis and fluid diagenesis, tectonic diagenesis shows two basic characteristics of abrupt change and nonthermal indicator.

\subsection{Abrupt change of tectonic diagenesis}

The paleotectonic stress and times of tectonic compression of the rocks were measured by the acoustic emission method (Table 1). There are at least six phases of tectonic compression during Mesozoic-Cenozoic in the Kuqa area. The lower Jurassic rocks in the outcrop section underwent 4-6 phases of tectonic compression in the Tugeerming area. There were 3-5 phases in Cretaceous of Yinan area and the Paleogene outcrop sections underwent tectonic compression 2-5 times in the Yinan and Tugeerming areas. The times of tectonic compression decreased from Jurassic to Tertiary, but it is difficult to accurately identify the geological epoch corresponding to each event's paleotectonic stress. Therefore, the integrated method of geological analysis and paleotectonic stress measured by acoustic emission is feasible to roughly judge the geological epoch of each phase of paleotectonic stress. The Mesozoic-Cenozoic can be divided into six paleotectonic events in the Kuqa area. The Himalayan movement was the main tectonic deformation period $(\mathrm{Lu}$ et al, 1999; Tang, 1996). There was a tectonic compression movement in the late Cretaceous and at least four tectonic compression movements in the Tertiary (Jia, 1997; Liu, 1996). According to previous research results (Liu et al, 2000; Lu et al, 1999), the tectonic deformation in the Kuqa area extended from north to south, and the geological ages of tectonic deformations were 25.0 Ma, 16.9 Ma, 5.3 Ma, 3.9 Ma, 2.5 $\mathrm{Ma}$, and 1.2 Ma, respectively. The results are consistent with the paleotectonic stress measured by acoustic emission, and then the geological ages of tectonic deformation and paleotectonic stress values could be estimated (Fig. 2). The curve before $25 \mathrm{Ma}$ in Fig. 2 was acquired based on regional tectonic evolution (Liu et al, 1996; 2000).

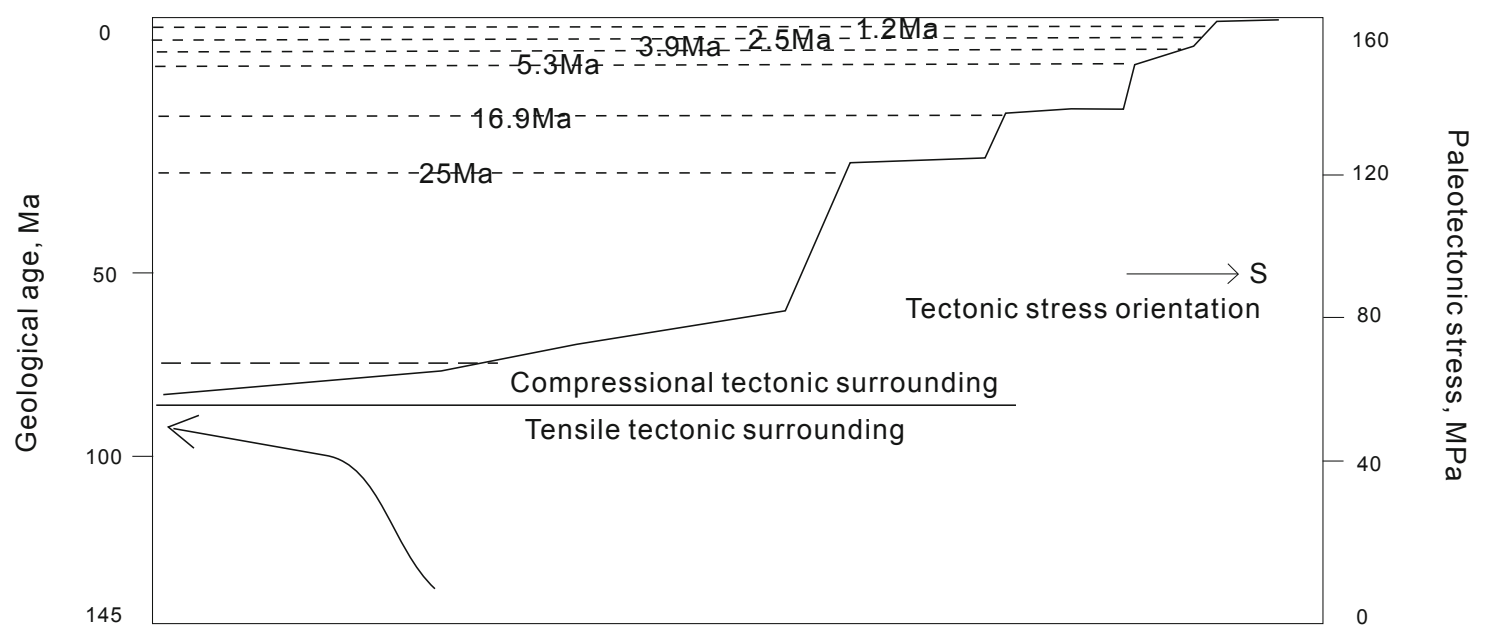

Fig. 2 Tectonic deformation phase and its palaeostructure stress of Mesozoic-Cenozoic sandstones in the Kuqa area, showing six phases of tectonic deformation measured by acoustic emission 
Table 1 Paleotectonic stress values and times in Mesozoic-Cenozoic measured by acoustic emission in the Kuqa area

\begin{tabular}{|c|c|c|c|c|c|c|}
\hline Sample source & \multirow{2}{*}{\multicolumn{3}{|c|}{$\begin{array}{c}\text { Outcrop of Tugeerming } \\
\text { Lower Jurassic }\end{array}$}} & \multicolumn{2}{|c|}{ Yinan area } & Outcrop of Tugeerming \\
\hline \multirow{2}{*}{$\begin{array}{c}\text { Sample horizon } \\
\text { Tectonic compression times }\end{array}$} & & & & Cretaceous & & aleogene \\
\hline & & 4 & 6 & 5 & 5 & 2 \\
\hline $\begin{array}{l}\text { Paleotectonic stress } \\
\text { of each time, } \mathrm{MPa}\end{array}$ & $\begin{array}{l}\text { 7.1, 21.7, } \\
28.2,31.4\end{array}$ & $\begin{array}{l}31.0,37.7 \\
49.6,67.2\end{array}$ & $\begin{array}{l}49.0,55.5,63.6 \\
69.0,76.4,95.7\end{array}$ & $\begin{array}{c}52.6,61.5,67.6, \\
76.8,87.2\end{array}$ & $\begin{array}{c}32.6,36.8,53.6, \\
68.2,98.1\end{array}$ & $45.8,72.6$ \\
\hline
\end{tabular}

From the early to the late periods, the paleotectonic compression stress became gradually larger. The paleotectonic compression stress in the first stage is usually smaller than $70 \mathrm{MPa}$, mostly between $30 \mathrm{MPa}$ and $50 \mathrm{MPa}$. In the second stage, it is smaller than $90 \mathrm{MPa}$, mostly between $40 \mathrm{MPa}$ and $70 \mathrm{MPa}$. In the third stage, it is usually smaller than 120 $\mathrm{MPa}$, mostly between $60 \mathrm{MPa}$ and $90 \mathrm{MPa}$. In the fourth and fifth stages, the paleotectonic stress is smaller than $140 \mathrm{MPa}$, mostly between $70 \mathrm{MPa}$ and $120 \mathrm{MPa}$. In the sixth stage, it is usually smaller than $165 \mathrm{MPa}$, mostly between $90 \mathrm{MPa}$ and $130 \mathrm{MPa}$. The Mesozoic-Cenozoic tectonic compression movement mainly happened after 25.0 Ma. Especially after 16.9 Ma, there were five phases of tectonic compression movements. Consequently, compared with thermal diagenesis, tectonic diagenesis happened over a very short time period.

The effect of tectonic diagenesis is obvious. Shou et al (2003; 2006a; 2006b; 2007) carried out a lot of research in this field, and obtained the relationship between the paleotectonic stress (Ps) and the porosity decrease value $\left(\phi_{\mathrm{st}}\right)$ of Cretaceous sandstone in southwest of the Tarim Basin and lower Jurassic in the Kuqa area (Fig. 3). The porosity decrease rate caused by tectonic compression stress is between $0.094 \% / \mathrm{MPa}$ and $0.1141 \% / \mathrm{MPa}$, with an average of $0.1051 \% / \mathrm{MPa}$. If computed by the biggest paleotectonic stress value of $156.2 \mathrm{MPa}$ that the lower Jurassic sandstone in Wuqiagou section has ever undergone, the biggest cumulative porosity decrease in the $25 \mathrm{Ma}$ stage is $16.4 \%$; that is to say, porosity decreased $0.7 \%$ per $1.0 \mathrm{Ma}$. The weak tectonic deformation area of Tarim Basin is under similar lithological conditions, the porosity decrease rate caused by thermal diagenesis is $0.22 \%-0.34 \%$ per $1.0 \mathrm{Ma}$, which is about $31 \%-49 \%$ of porosity decrease value caused by tectonic diagenesis. The values are averages over time, and in fact tectonic diagenesis takes place in a very short time relative to thermal diagenesis. For example, the porosity decrease in lower Jurassic sandstone caused by the first tectonic deformation is $5.5 \%$ in the Wuqiagou area, showing the abrupt change characteristics of tectonic diagenesis. Each tectonic deformation made an abrupt change of sandstone compaction in very short time, and many periods of tectonic deformation would cause multiple abrupt changes of tectonic diagenesis compaction.

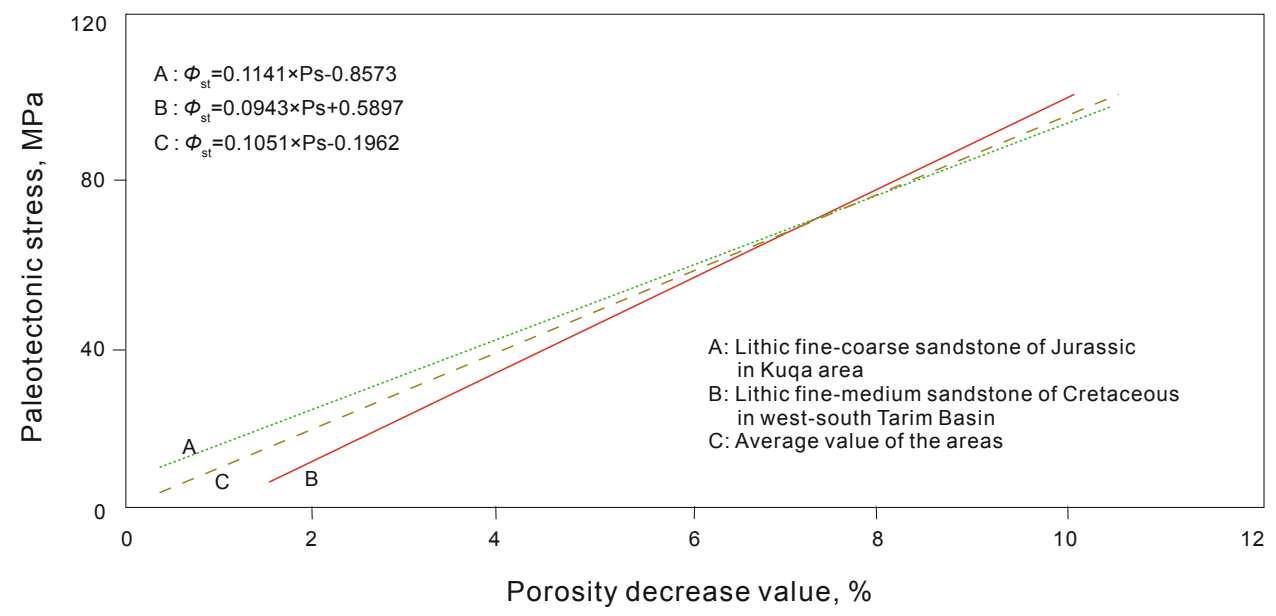

Fig. 3 Relationship between the paleotectonic stress (Ps) and porosity decrease value $\left(\phi_{\mathrm{st}}\right)$ in the Tarim Basin

\subsection{Nonthermal indications of tectonic diagenesis}

According to the above discussion, tectonic diagenesis mainly affected the rocks' compaction in physical ways, so it is obviously different from thermal diagenesis. That is to say, the thermal diagenesis indicators (e.g. vitrinite reflectance and time-temperature index) can show the thermal diagenesis compaction, but can not show the characteristics of tectonic diagenesis. So the sandstone compaction after tectonic diagenesis was stronger than that of thermal diagenesis alone. The stronger the tectonic deformation, the more difference between tectonic and thermal diagenesis. 
For example, the vitrinite reflectance of the lower Jurassic is $0.55 \%$, and time-temperature index is 6.3 in the south limb of the Tugeerming anticline in the Kuqa area, indicating the thermal diagenesis evolution period from the early diagenesis $\mathrm{B}$ middle period to the late diagenesis $\mathrm{A}_{1}$ middle period. The vitrinite reflectance and time-temperature index of the lower Jurassic in the north limb of Tugeerming anticline are $0.65 \%$ and 12.8 , respectively, indicating the thermal diagenesis evolution period from the early diagenesis $\mathrm{B}$ late period to the late diagenesis $A_{1}$ early period (Table 2 ). The clastic grains of sandstone in the north limb mainly contact with each other in the way of line and embedment, and the measured porosity is only $4.3 \%$, reflecting very strong compaction. The Tuha Basin has similar phenomena: in the hinterland of the basin, the tectonic deformation is very weak, and thermal diagenesis compaction stage of sandstone is consistent with actual sandstone compaction stage. For example, the vitrinite reflectance is $0.55 \%$ and time-temperature index is 4.5 in the depth of $2,148-2,202 \mathrm{~m}$ in well Aishen-1, suggesting the thermal diagenesis evolution stage from the early diagenesis $\mathrm{B}$ to the late diagenesis $\mathrm{A}_{1}$. Clastic grains contact with each other in the way of spot and spot-line, showing a characteristic of early diagenesis stage. However, in the piedmont zone where the tectonic deformation is very strong, the sandstone's thermal diagenesis compaction is much lower than the actual compaction. For example, the vitrinite reflectance is $0.5 \%$ in the depth of 2,174-2,788 $\mathrm{m}$ of well Zhao-2, reflecting the thermal diagenesis evolution stage from the early diagenesis $B$ to the late diagenesis $A_{1}$ early period. The clastic grains contact with each other in the way of line and embedment, and planar porosity is almost zero under the petrographic microscope. The measured porosity is smaller than $6 \%$, showing very strong diagenesis compaction. The well Wusu-1 and well Le-7 also showed this kind of diagenesis characteristics, and the nonthermal indicator was caused by very strong tectonic compression events.

Table 2 Contrast of thermal and actual diagenesis compaction degree in the Tuha and Tarim basins

\begin{tabular}{|c|c|c|c|c|c|c|c|c|c|}
\hline \multirow{2}{*}{$\begin{array}{c}\text { Tectonic } \\
\text { background }\end{array}$} & \multirow{2}{*}{ Sample source } & \multirow{2}{*}{$\begin{array}{l}\text { Sample } \\
\text { horizon }\end{array}$} & \multirow{2}{*}{$R_{\mathrm{o}}, \%$} & \multirow{2}{*}{$\begin{array}{l}\text { Time- } \\
\text { temperature } \\
\text { index }\end{array}$} & \multicolumn{2}{|c|}{$\begin{array}{c}\text { Early } \\
\text { diagenesis }\end{array}$} & \multicolumn{3}{|c|}{ Late diagenesis } \\
\hline & & & & & $A$ & B & $\mathrm{A}_{1}$ & $\mathrm{~A}_{2}$ & B \\
\hline \multirow{4}{*}{$\begin{array}{c}\text { Piedmont Belt } \\
\text { of Kuqa }\end{array}$} & $\begin{array}{l}\text { South limb of } \\
\text { anticline surface } \\
\text { inTugeerming }\end{array}$ & \multirow{3}{*}{$\begin{array}{l}\text { Lower } \\
\text { Jurassic }\end{array}$} & 0.55 & 6.3 & & & & & \\
\hline & $\begin{array}{c}\text { North limb of } \\
\text { anticline surface } \\
\text { inTugeerming }\end{array}$ & & 0.65 & 12.8 & & & & & \\
\hline & well Yinan-2 & & 0.85 & 55 & & & & & \\
\hline & well Dongqiu-8 & Cretaceous & & & & & & & \\
\hline \multirow{3}{*}{$\begin{array}{l}\text { Weak tectonic } \\
\text { diagenesis } \\
\text { area in Tuha } \\
\text { Hinterland Belt }\end{array}$} & well Aishen-1 & \multirow{6}{*}{ Tertiary } & 0.55 & 4.5 & & & & & \\
\hline & well Lu-1 & & & 4.1 & & & & & \\
\hline & well Yu-1 & & 0.65 & 22.5 & & & & & \\
\hline \multirow{3}{*}{$\begin{array}{c}\text { Strong tectonic } \\
\text { diagenesis } \\
\text { area in Tuha } \\
\text { Piedmont Belt }\end{array}$} & well Zhao-2 & & 0.5 & & & & & & \\
\hline & well Wusu-1 & & 0.67 & 29.8 & & & & & \\
\hline & well Le-7 & & & $64-115$ & & & & & \\
\hline
\end{tabular}

Thermal diagenetic compaction degree 


\section{Tectonic diagenesis classification}

Tectonic diagenesis can be classified according to the tectonic deformation style and the different diagenesis evolution features. Based on current research, the MesozoicCenozoic developed four types of tectonic diagenesis including rigid rock restraint, fault ramp, low angle fault slippage, and napping.

\subsection{Tectonic diagenesis model of rigid rock restraint}

The Tugeerming outcrop anticline is a typical example of rigid rock restraint tectonic diagenesis. The paleotectonic stresses of four samples from the south and north limbs of Tugeerming anticline, respectively, were tested by acoustic emission (Fig. 4). Four phases of paleotectonic stress were measured in the south limb samples (because of the cracks in sample A, only two phases of stress were measured), and the paleotectonic stress increased from limb to axis of the anticline. Six paleotectonic stress phases were measured in sample D, and two were measured in sample E. The paleotectonic stress in the north limb is significantly bigger than that in the south limb, having the tendency of increasing from limb to axis of the anticline.

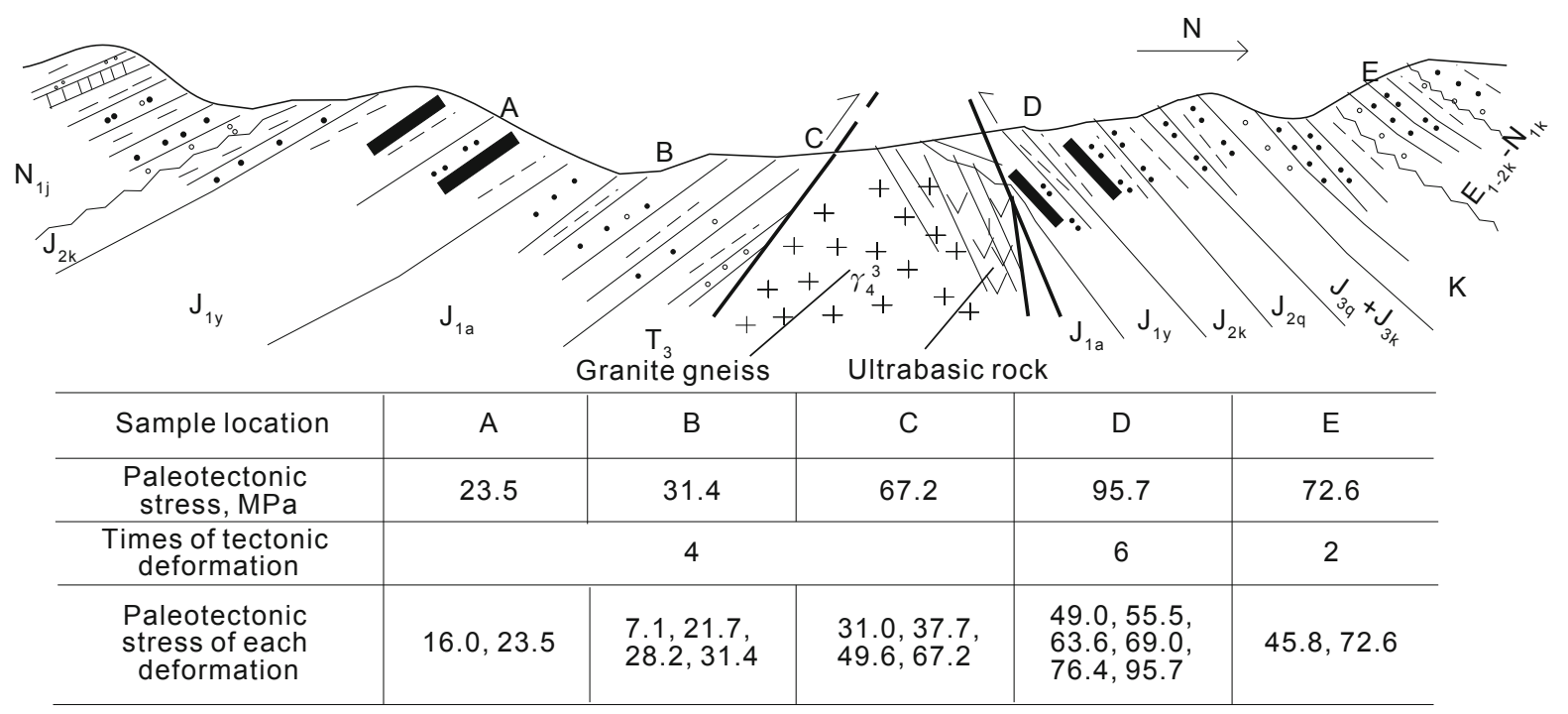

Fig. 4 Tectonic deformation phase and its paleotectonic stress in the north and south limbs of Tugeerming anticline. A, B, C, D, and $\mathrm{E}$ stand for five phases of tectonic deformation, respectively

Based on analyzing the controlling factors of sandstone tectonic diagenesis in the south and north limbs of the anticline, we concluded that there was a great difference of the sandstone tectonic compaction between the south and north limbs. In detail, the tectonic compaction amount of south limb is $2.3 \%-3.5 \%$, and the north limb is $10.3 \%$, so the difference is $6.8 \%-8.0 \%$, accounting for $73.9 \%-87.0 \%$ of total difference in sandstone compaction between the south and north limbs (Shou et al, 2007). In the south limb of the anticline, the sandstone's thermal compaction accounts for $58.3 \%$ of the total compaction amount, while the tectonic compaction amount only accounts for $11.5 \%-17.5 \%$, meaning that thermal compaction is the main factor for the porosity decrease of sandstone in the south limb. In the north limb, the tectonic compaction accounts for $35.3 \%$ of the total compaction amount, indicating that tectonic compaction became obviously stronger. The change of tectonic diagenesis was controlled by regional tectonic compressive stress and the restraint of rigid rock (Fig. 5). The north limb was compacted strongly by tectonic stress from the north orogen, producing $10.3 \%$ tectonic compaction. Through the transmitting process of tectonic stress from south to north, because of the restraint of rigid rock, the tectonic compression stress obviously decreased in the south limb or passive limb, only producing $3.5 \%$ compaction. Without rigid rock restraint, tectonic compression stress still decreased in the transmitting process. According to the analysis of space changing characteristics of tectonic stress in the Kuqa area, there were no obvious changes in a very short distance. The increase of tectonic stress (sample $\mathrm{C}$ in Fig. 4) close to rigid rock may be related to the compressive stress generated by rock invasion.

\subsection{Tectonic diagenesis model of fault ramp}

The fault ramp of the Kela 2 area is an example of tectonic diagenesis of this type. It developed two main ramps influenced by the Paleogene gypsum-salt beds, and a largescale detachment surface developed in underlying lower Jurassic strata (Fig. 6). The middle broad anticline is the large gas field of Kela 2, and its reservoir is mainly medium to fine lithic sandstone rich in primary pores in the Cretaceous Bashijiqike Member. The sandstone sorting is moderate, and argillaceous matrix content is $3.0 \%-6.0 \%$, with little differences from the original sandstone depositional fabric within this area. The granular diameter, burial depth, and tectonic stress are the main factors affecting the evolution of sandstone porosity, and tectonic stress is very important to 


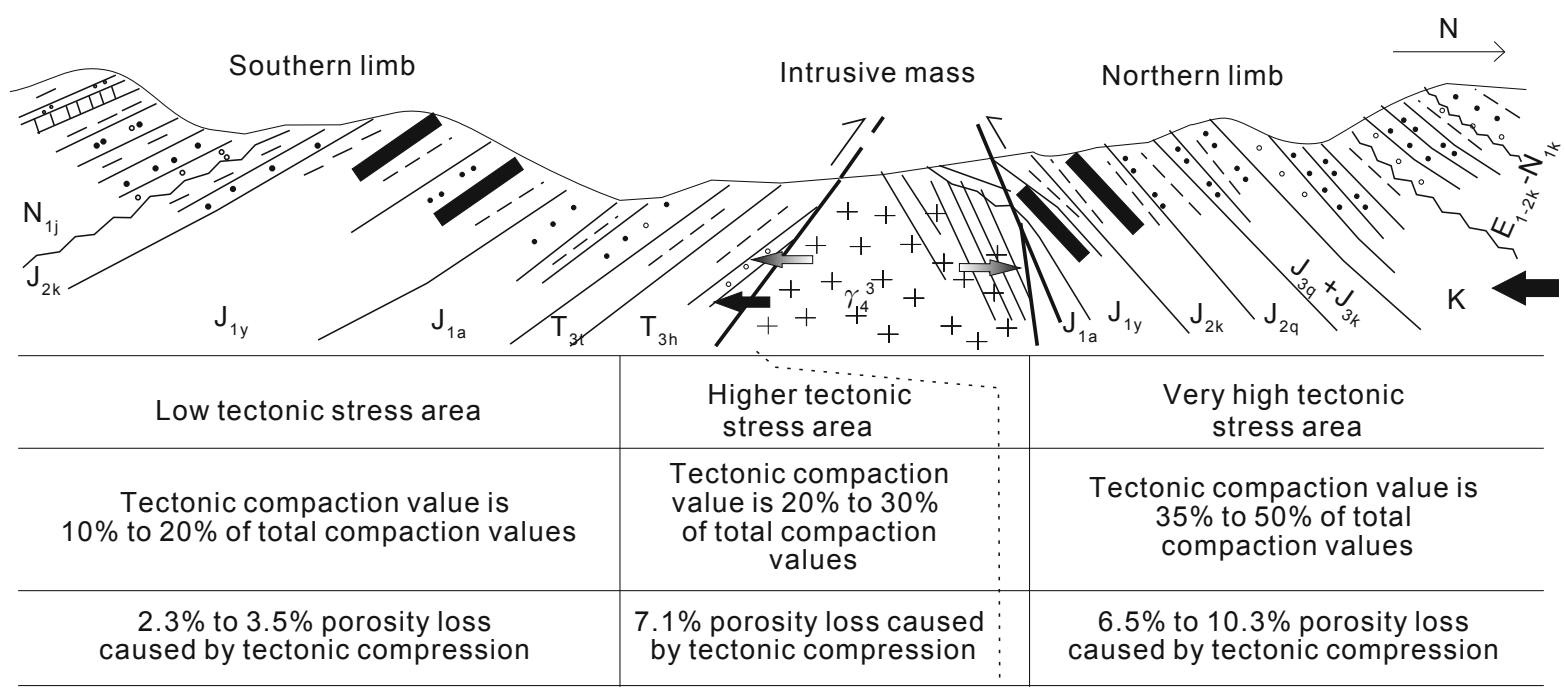

Compressive stress of volcanic intrusion

Orogenic compressive stress

Fig. 5 Tectonic diagenetic model of rigid rock restraint from Tugeerming anticline

the porosity preservation of sandstone. The regional tectonic compressive stress during Neogene produced two ramp faults, and the upward stress of the two faults decreased the static pressure of overlying formation, which was favorable to porosity preservation of sandstone in the lower wall of ramp faults.

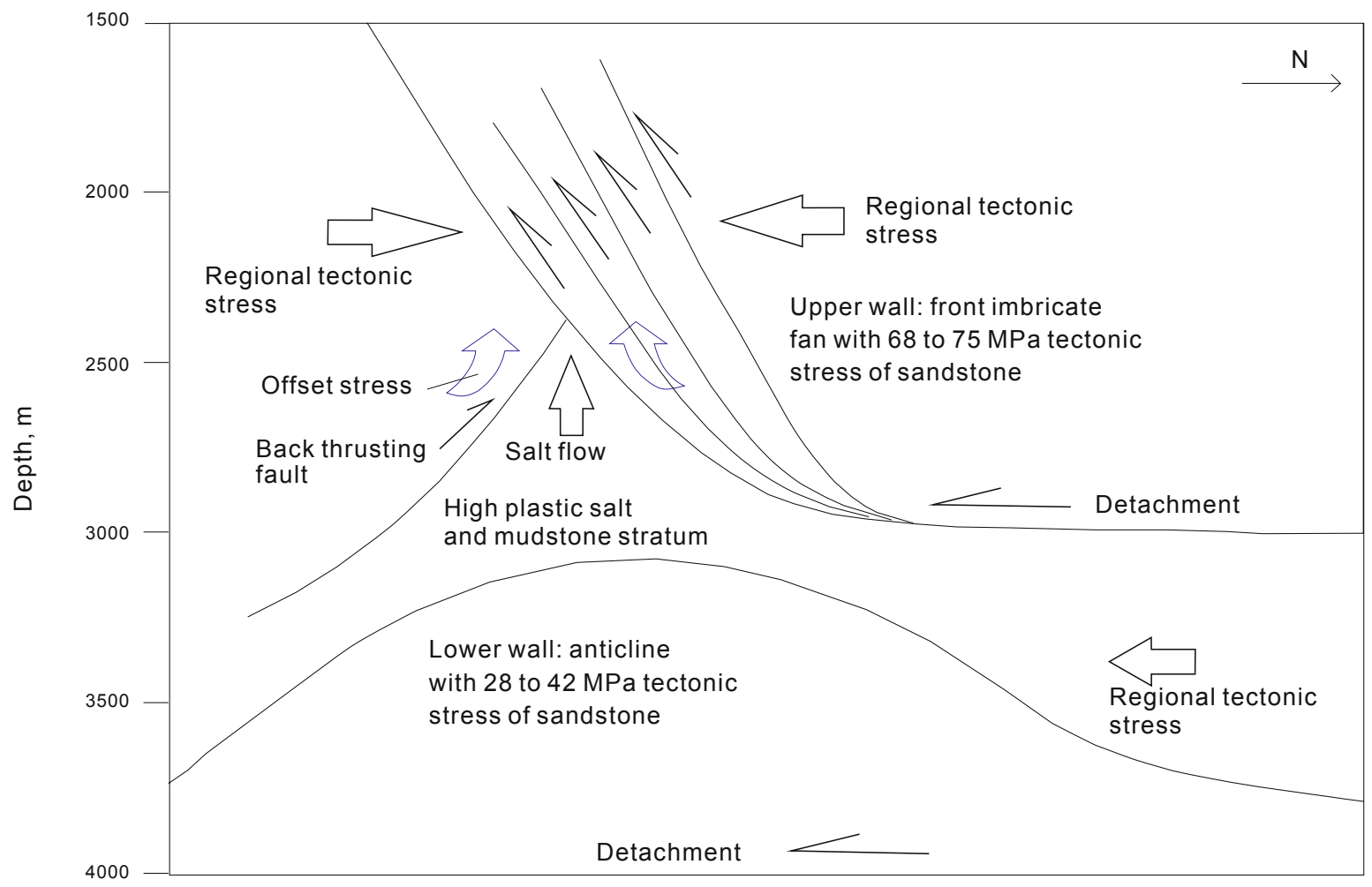

Fig. 6 Tectonic diagenetic model of fault ramp from Kela structural belt of the Kuqa area

The Cretaceous paleotectonic stress in the upper wall of the ramps was estimated from log response characteristics (Zhao et al, 2005; Li et al, 2004), and then the results were adjusted by correlation between Cretaceous log results and actual paleotectonic stress. The acquired paleotectonic stress was $68.0-75.0 \mathrm{MPa}$ and the porosity decrease was $7.2 \%$ $7.9 \%$. The paleotectonic stress measured by acoustic emission method in the lower wall of ramps was 28.0-42.0 MPa, and the porosity decrease was $2.9 \%-4.4 \%$. The compaction of sandstone in the lower wall of the ramps decreased $3.2 \%-3.5 \%$ 
because of the difference of paleotectonic stress between the upper wall and lower wall. In order to verify this conclusion, for example taking the fine sandstone of the Bashijiqike Member, which is well sorted, with argillaceous matrix content of $2.0 \%-3.0 \%$, the sandstone compaction of the lower wall was analyzed further. After computation, the actual compaction is $10.6 \%-12.1 \%$, while the compaction in the Tarim Basin with similar lithology condition is about $16.4 \%$, $4.3 \%-5.8 \%$ more than the actual compaction amount, which is almost consistent with the results concluded by paleotectonic stress analyses.

\subsection{Tectonic diagenesis model of low angle fault slippage}

The Yinan structure developed an imbricated low angle slipping reverse fault, which was generated by regional tectonic compressive stress from the north. The upper wall and lower wall of the fault are both lower Jurassic lithic sandstone with good original deposition fabric. The granular diameter, thermal maturity, and tectonic compression stress were the main controlling factors of sandstone's compaction (Shou et al, 2001). This area was under a very strong regional tectonic compression, and the current measured paleotectonic stress is usually above $75.0 \mathrm{MPa}$, which is a very important controlling factor for sandstone compaction. There are great differences in paleotectonic stress values and times between the upper and lower walls. Three phases of paleotectonic stress were recorded in upper wall of the fault, and five in the lower wall (Table 3 ). The difference in the maximum paleotectonic stress between the upper wall and lower wall is $40.8 \mathrm{MPa}$, and the corresponding sandstone compaction difference is $5.0 \%$; that is to say, the tectonic compaction of upper wall is $5.0 \%$ smaller than that of the lower wall.

Table 3 Tectonic deformation times and stress of the fault

\begin{tabular}{|c|c|c|c|c|c|}
\hline Times of tectonic stress & 1 & 2 & 3 & 4 & 5 \\
\hline $\begin{array}{l}\text { Paleotectonic stress } \\
\text { of upper wall, } \mathrm{MPa}\end{array}$ & 17.5 & 37.7 & 57.3 & & \\
\hline $\begin{array}{l}\text { Paleotectonic stress } \\
\text { of lower wall, } \mathrm{MPa}\end{array}$ & 32.6 & 36.8 & 53.6 & 68.2 & 98.1 \\
\hline
\end{tabular}

The difference of number and intensity of paleotectonic stress phases between the upper wall and lower wall of the fault may be caused by the occurrence of the reverse fault and the relationship between fault slipping and the tectonic compression period. When the dip angle of reverse fault is small, there is a movement along the tectonic stress direction in the upper wall. When the first three tectonic compression phases happened, there was a little upward movement in the upper wall of the fault, making the upper wall and lower wall both influenced by tectonic stress (Fig. 7). The second and third phases paleotectonic stress are similar, and the upper wall's is a little bigger than the lower wall's, according with the rule that the stress increases during the transmitting process. The first paleotectonic stress phase in the lower wall was obviously bigger than that in the upper wall (Table 3). When the last two phases of tectonic compression happened, the slippage amount of the upper wall was large, making it far from the horizontal principal stress plane, so the last two phases tectonic compressive stress were not recorded. The lower wall still suffered the last two phases tectonic stress as high as $98.1 \mathrm{MPa}$, making a great difference of porosity decrease between the upper and lower walls.

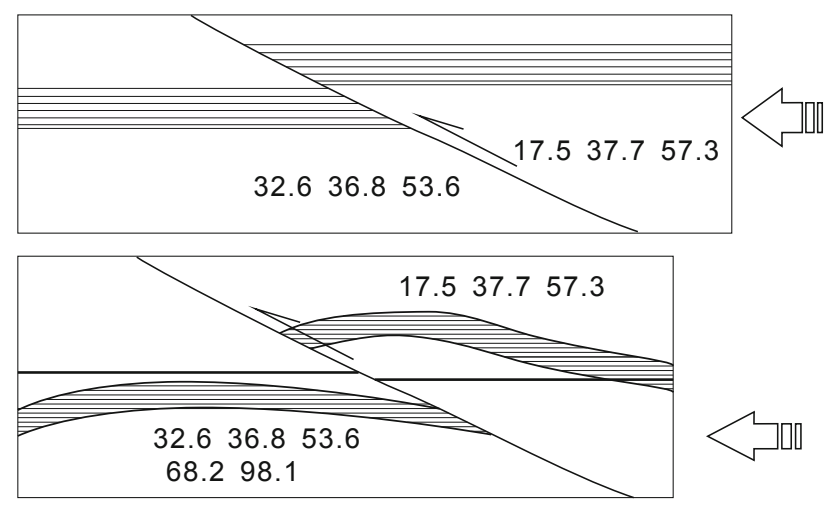

Fig. 7 Tectonic diagenetic model of low angle fault slippage from Yinan area, arrowhead stands for the regional tectonic stress

\subsection{Tectonic diagenesis model of napping}

Tectonic napping has been intense in the sedimentary basins in middle and west of China, and has important influence on the diagenetic evolution of sandstone. The piedmont structural belt and Qiulitage structural belt in the Kuqa area, as well as the Huoyanshan-Qiketai structural belt in the Tuha Basin all developed huge tectonic napping in the Himalayan period, which influenced diagenesis evolution through changing the thermal maturity of sandstone. Tectonic napping happened in Oligocene with a nappe thickness of 3,400 $\mathrm{m}$ in well Dabei-3 in the Kuqa area (Fig. 8 ), making the time-temperature index of sandstone only 52 in the buried depth of $7,000 \mathrm{~m}$, far below that in neighboring area where no late tectonic napping happened. The study of tectonic diagenesis of the Triassic sandstone in the Tuha Basin showed that the thermal maturity of sandstone (i.e. time-temperature index) of Kelamayi Formation, in well Donghu-1 where tectonic napping happened was 30 smaller than that of the area where tectonic napping did not happen, leading to the sandstone compaction obviously decreasing. The sandstone compaction amount of well Donghu-1 is $6 \%$ smaller than that of the area where the tectonic compression was weak, and is $13 \%$ smaller than that of the submountain region with strong tectonic compression. As shown in Fig. 8, the time of tectonic napping influenced the thermal maturity of sandstone and controlled the diagenesis evolution. The earlier the tectonic napping happened, the higher the thermal maturity was, and the porosity decrease value also increased. 


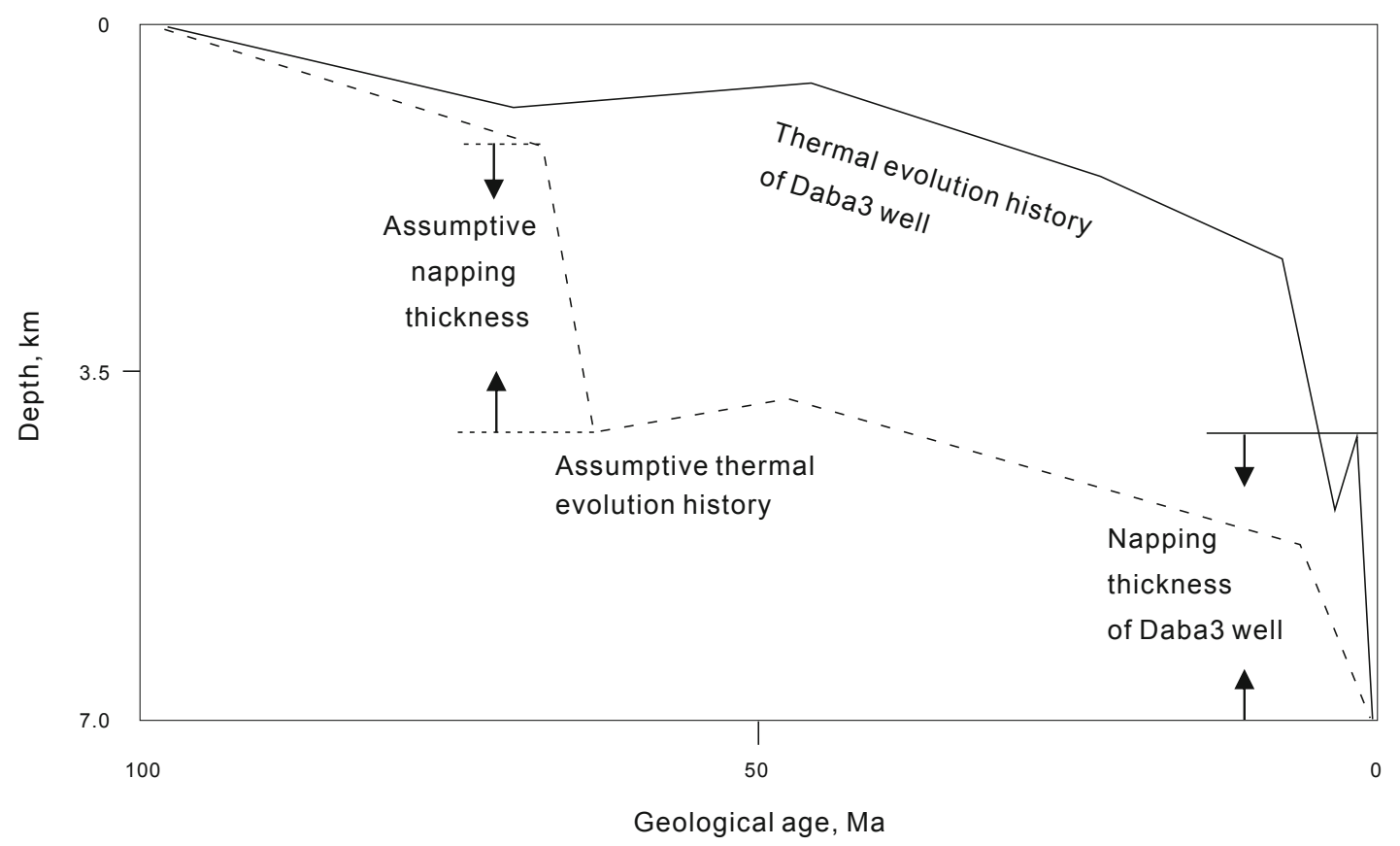

Fig. 8 Thermal evolution histories of napping diagenetic model

\section{Conclusions and discussion}

Intense tectonic deformation of Mesozoic-Cenozoic in the Kuqa area has left traceable vestiges for the study of the sandstone's tectonic diagenesis. Tectonic diagenesis is characterized by abrupt change and nonthermal indicator. Tectonic diagenesis mainly influenced the sandstone's compaction evolution by physical pathways. The porosity decreased by $0.105 \%$ with tectonic compressive stress increasing 1.0 $\mathrm{MPa}$. The reservoir type and fluid flow condition were changed by fractures generated by tectonic diagenesis. Tectonic diagenesis changed the stress distribution through changing the tectonic deformation styles, and then caused different tectonic diagenesis effects. Accordingly, Mesozoic-Cenozoic tectonic diagenesis in the Kuqa area can be divided into four types: rigid rock restraint, fault ramp, low angle fault slippage and napping.

The tectonic deformation of Mesozoic-Cenozoic in the Kuqa area is really complex, so the above four types of tectonic diagenesis can not summarize it fully. The detailed relationship between tectonic evolution history and diagenesis evolution remains to be studied. Firstly, the time when the tectonic deformation happened can only be judged by geological analysis. Secondly, the sandstone's components and textures, as well as the compaction degree or porosity preservation degree when the tectonic deformation happened, still need more in-depth study. Further research on these problems will be beneficial to understand more fully sandstone diagenesis in tectonic compression sedimentary basins in China.

\section{References}

Ding Y C, Sun B S, Wang X H, et al. Present stress state determined by AE in the Northern Tarim Oil Field. Earth Science-Journal of China University of Geosciences. 1997. 22(2): 215-218 (in Chinese)

Gu J Y, Fang H and Jia J H. Diagenesis and reservoir characteristics of Cretaceous braided delta sandbody in Kuqa Depression, Tarim Basin. Acta Sedimentologica Sinica. 2001. 19(4): 517-523 (in Chinese)

Jia C Z. Structural Feature and Oil and Gas of the Tarim Basin in China. Beijing: Petroleum Industry Press. 1997 (in Chinese)

Kuang H W, Gao Z Z, Zhai Y H, et al. Characteristics of Tertiary reservoir in Kuqa Depression of Tarim Basin. Acta Petrolei Sinica. 2003. 24(1): 25-30 (in Chinese)

Li J, Zhang C M, Wang G W, et al. Terrestrial-stress logging responding characteristics of piedmont tectonic belt and its influence on reservoir property. Acta Petrolei Sinica. 2004. 25(3): 23-27 (in Chinese)

Liu B P. Tectonic Framework and Evolution of the Southwest Tianshan Mountain. Beijing: China University of Geosciences Press. 1996 (in Chinese)

Liu H T and Zeng L B. Expression of the Himalayan orogeny in the Kuqa Depression, Tarim Basin-evidence from the rock acoustic emission experiment. Geological Bulletin of China. 2004. 23(7): 676679 (in Chinese)

Liu Z H, Lu H F, Li X J, et al. Tectonic evolution of Kuqa Rejuvenated Foreland Basin. Scientia Geologica Sinica. 2000. 35(4): 482-492 (in Chinese)

Lu H F, Jia D, Chen C M, et al. Nature and timing of the Kuqa Cenozoic structures. Earth Science Frontiers. 1999. 6(4): 215-221 (in Chinese)

Qiu X P, Lü G X, Wu H L, et al. Preliminary study on tectonic frictional heat. Acta Geoscientia Sinica. 1998. 19(2): 132-136 (in Chinese)

Shou J F, Si C S and Wang X. Genesis types and diagenesis compaction mechanisms of sandstone reservoirs in dynamic environments in oil/ gas basins in China. Petroleum Science. 2006a. 3(3): 23-31

Shou J F, Si C S, Zhu G H, et al. Control factors of the properties of the lower Jurassic sandstone reservoirs in the Kuqa Depression, Tarim Basin. Geological Review. 2001. 47(3): 273-277 (in Chinese)

Shou J F, Zhang H L and Shen Y. The analysis of controlling factors on sandstone diagenesis and porosity preservation of lower Juarassic in Tugerming Anticline, Kuqa Foreland Basin. Acta Sedimentologica 
Sinica. 2007. 25(6): 869-875 (in Chinese)

Shou J F, Zhang H L, Shen Y, et al. Diagenetic mechanisms of sandstone reservoirs in China oil and gas-bearing basins. Acta Petrologica Sinica. 2006b. 22(8): 2165-2170 (in Chinese)

Shou J F, Zhu G H and Zhang H L. Lateral structure compression and its influence on sandstone diagenesis - a case study from the Tarim Basin. Acta Sedimentologica Sinica. 2003. 21(1): 90-95 (in Chinese)

Tang L J. Basin Evolution and Tectonic Styles in Tarim Basin. Beijing: Geological Publishing House. 1996. 41-73 (in Chinese)

Wang G H and Shou J F. The relationship between the characteristics of sand bodies and the properties of lower Jurassic reservoirs in eastern Kuqa Depression, Tarim Basin. Petroleum Exploration and
Development. 2001. 28(4): 33-35 (in Chinese)

Yang F, Sun Y S, Tan X C, et al. Formation mechanism of Paleogene low permeability reservoir in Dina 2 Gas Field, Tarim Basin. Petroleum Exploration and Development. 2005. 32(2): 39-42 (in Chinese)

Zhang M L, Tan C X, Tang L J, et al. An analysis of the MesozoicCenozoic tectonic stress field in Kuqa Depression, Tarim Basin. Acta Geoscientia Sinica. 2004. 25(6): 615-619 (in Chinese)

Zhao J, Peng W, Li J F, et al. In-situ stress logging responding characteristics of Piedmont Thrust Belt and its influence on hydrocarbon distribution. Earth Science-Journal of China University of Geosciences. 2005. 30(4): 465-472 (in Chinese)

(Edited by Hao Jie) 